\title{
MENEROPONG SMART CITY KOTA JAMBI DARI PERSPEKTIF KEBERLANJUTAN DAN POLA PENGEMBANGAN KAMPUNG BANTAR
}

\author{
Hafizoh Yuelsa Bela \\ Program Studi Ilmu Pemerintahan \\ Universitas Jambi, Jambi, Indonesia \\ hafizohyuelsa@gmail.com
}

\begin{abstract}
Abstrak
Program kampung bantar Kota Jambi berhasil mendapatkan prestasi dan pengakuan secara internasional yang mewujudkan Kota Jambi sebagai smart city. Namun ditengah keberhasilan pemeritah tersebut terdapat beberapa permasalahan Kota serta tantangan yang dihadapi oleh pemerintah sejalan dengan perkembangan industri yang menjadi isu negara dunia yakni era revolusi industri 4.0. Tulisan ini berfokus pada permasalahan perkotaan dan tantangan yang dihadapi Kota Jambi dalam mewujudkan smart city dibalik kesuksesannya. Metode yang digunakan dalam penelitian ini adalah kualitatif. Penelitian ini juga membutuhkan data primer diperoleh dari wawancara mendalam dengan beberapa narasumber sedangkan data sekunder diperoleh dari berbagai dokumen pemerintah daerah Kota Jambi yang dapat mendukung penelitian ini. Dalam menganalisis data dilakukan secara deskriptif kualitatif yakni data yang terkumpul akan dikategorisasi, kemudian dianalisis secara deskriptif hingga diperoleh kesimpulan berupa permasalahan Kota dan tantangan apa saja yang dihadapi oleh Kota Jambi dalam mewujudkan smart city. Hasil penelitian ini menunjukkan berbagai permasalahan yang dihadapi oleh pemerintah Kota Jambi dan tantangan yang paling utama adalah pembangunan sumber daya manusia baik aparatur pemerintah maupun masyarakat yang berkualitas demi mewujudkan smart city, namun dibalik itu semua smart city Kota Jambi mampu menunjukkan eksistensinya sebagai potensi dalam menyelesaikan masalah perkotaan di Kota Jambi.
\end{abstract}

Kata Kunci : Kampung Bantar, Smart City, Tantangan, Permasalahan Kota, Revolusi Industri 4.0

\begin{abstract}
Abstact
Kampung Bantar as successful program in Jambi city has gotten international achievement and recognition that has made Jambi as smart city. However, there are several problems and challenges will be faced by the government then it is going through in the era of industry development which became an issue of the world state called industrial revolution 4.0. This paper will focus on urban problems and challenges facing the city of Jambi in realizing smart city. The method used in this research is qualitative. This study also requires primary data obtained from in-depth interviews with several sources while secondary data obtained from various local government documents which is able to support this research. Analyzing data descriptively qualitative, the data collected will be categorized, then analyzed descriptively until conclusions are obtained in the form of city problems and what challenges will be faced by the city of Jambi in realizing smart city. The result of this study is indicate a variety of problems facing by Jambi city government and the most important challenge is the development of human resources both government officials and qualified people to realize smart city, beside smart city of Jambi city indicates their existence as number one of solution urban problems in Jambi city.
\end{abstract}

Key Word : Kampung Bantar, Smart City, Chalange, urban problems, Industrial Revolution 4.0 


\section{PENDAHULUAN}

Kota merupakan lingkungan yang terbentuk dalam kurun waktu yang lama, didalamnya terjadi proses perkembangan yang dipengaruhi oleh berbagai faktor diantaranya ekonomi, politik, sosial dan budaya. Hingga dimasa sekarang, Kota menunjukkan perkembangan yang begitu pesat, Kota juga merupakan pusat segala kegiatan pemerintahan, ekonomi dan kebudayaan sehingga ruang-ruang Kota diisi dengan berbagai aktivitas yang sangat kompleks ditambah dengan populasi penduduk yang padat menyebabkan kebutuhan dan peranan yang terdapat didalamnya pun semakin bertambah. Lebih dari setengah populasi dunia kini bermukim di Kota, diperkirakan oleh Mohanty dkk bahwa pada tahun 2050, 70\% populasi dunia akan tinggal di perkotaan (Mohanty, Saraju dkk, 2017 : 2). Di Indonesia, terjadi peningkatan yang sama, Kementerian Pembangunan Nasional/ Bappenas memprediksi dengan mengukur tingkat pertumbuhan penduduk diperkotaan 2,75\% pertahun, lebih besar dari nasional 1,17 \% pertahun, pada tahun 2015 59,35\% penduduk sudah hidup di Kota, semakin tahun mengalami peningkatan sehingga diprediksi pada tahun 2045 populasi penduduk yang tingga di perkotaan mencapai 82,37\% (Direktur Perkotaan dan Pedesaan Kementerian PPN/Bappenas, 2015). Padatnya populasi penduduk diperkotaan menyebabkan semakin kompleksnya permasalahan yang akan muncul seperti menigkatnya penggunaan energi listrik, angka kriminalitas, kurangnya SDM, lingkungan yang tercemar akibat polusi udara dan lainnya ditambah dengan kebutuhan Kota yang harus dipenuhi.

Dalam menghadapi tantangan ini, Smart City menjadi sebuah konsep yang tengah dirancang oleh seluruh dunia sebagai solusi atas permasalahan Kota. Tidak ada definisi global mengenai smart city namun, smart city dapat diartikan sebagai sebuah konsep yang bersifat fleksibel, efisiensi layanan dan berkelanjutan dengan memanfaatkan perkembangan teknologi informasi dan komunikasi (Mohanty, Saraju dkk, 2017 : 1) Sehingga pemeritah dituntut untuk mengenal kebutuhan dan karakteristik Kotanya dalam membuat kebijakan yang tepat. Pada dasar smart city adalah sebuah konsep yang dirancang untuk meningkatkan efesiensi layanan dan memenuhi kebutuhan masyarakat perkotaan secara berkelanjutan.

Begitu halnya dengan Indonesia, berdasarkan asas desentralisasi pemerintah daerah memiliki kewenangan dalam memenuhi kebutuhan dan menyelesaikan persoalan yang ada. Beberapa Kota di Indonesia yang telah menerapkan smart city yakni Yogyakarta dan Surbaya, tak ingin kalah, dalam perkembangannya pemerintah Kota Jambi telah berhasil menerapkan 
konsep smart city dalam menjawab tantangan dan isu global yang tengah dihadapi oleh Kota di seluruh dunia. Kampung Bantar menjadi inovasi yang ditawarkan oleh pemerintah Kota Jambi yakni pendekatan yang berbasis pada pemukiman. Bantar sendiri merupakan singkatan dari Bersih, Aman dan Pintar yang merupakan komponen dari smart city. Inovasi ini diujukan dalam mengakselerasi perumbuhan pembangunan Kota dengan mengedepankan konsep pembangunan melalui sistem terkecil berbasis RT yang bertujuan untuk mengurangi ketimpangan pembangunan antar wilayah, meningkatkan kualitas kesejahteraan dan kualitas perkenomian masyarakat. Sejak dikembangkannya kampung bantar pada tahun 2014, pemerintah Kota jambi dapat mengimplementasikan inovasi Kota cerdas ini dengan baik, Faktanya dengan inovasi ini pemerintah daerah menuai banyak penghargaan hingga menarik dimata dunia internasional. Salah satu program inovasi yang menjadi Nominator Peace Prize for Local Government di Bogota pada UCLG 2016 yakni kampung Bantar (Bersih, Aman dan Pintar). Program ini mendorong masyarakat Kota Jambi berlomba menjadikan wilayahnya sebagai kampung bantar.

Ditengah gencarnya kampung bantar yang menjadi program unggulan pemerintah Kota dengan berbagai penghargaan yang diperoleh hingga diakui secara internasional. Dibalik kesuksesan tersebut terdapat berbagai permasalahan yang didahapi oleh pemerintah mengenai perkotaan. Belum lama ini Jakarta sebagai ibuKota negara dicap sebagai Kota dengan polusi udara terburuk didunia, diakibatkan oleh laju urbanisasi, kendaraan pribadi dan umum yang angkanya meningkat setara dengan bertambahnya populasi penduduk. Isu yang tengah hangat di dunia yakni pertumbuhan pembangunan industri pada era saat ini yang disebut sebagai revolusi industri 4.0 yakni Industri yang berhubungan secara digital yang mencakup berbagai jenis teknologi, mulai dari 3D printing hingga robotik yang disinyalir mampu meningkatkan produktivitas (Venti Eka Setya, 2018 : 20). Revolusi Industi 4.0 memiliki keterkaitan dengan smart city, yakni terdapat pada penggunaan teknologi dalam memanfaatkan sumber daya secara efisien dan efektif. Tumbuhnya perkembangan industri ini sejalan dengan pengembangan smart city di Kota Jambi. Sejauh mana persiapan Kota

Untuk itulah penelitian ini bertujuan untuk mengetahui permasalahan dan tantangan yang akan dihadapi oleh pemerintah Kota Jambi sehingga smart city di Kota Jambi dapat diimplementasikan secara berkelanjutan. 


\section{METODELOGI}

Metode yang digunakan dalam penelitian ini adalah kualitatif dengan peneliti sebagai instrumen sebagai instrumen kunci, teknik pengumpulan data dilakukan secara trianggulasi (gabungan), analisis data bersifat induktif, dan hasil penelitian kualitatif lebih menekankan makna dari pada generalisasi (Sugiyono 2012: 1). Penelitian ini berhubungan dengan ide, persepsi, pendapat atau kepercayaan orang yang diteliti dan kesemuanya tidak dapat diukur dengan angka, maka dari itu pada penelitian ini tidak menggunakan kuesioner sebagai instrument pengumpulan data. Sedangkan untuk instrument dalam penelitian kualitatif adalah peneliti (human instrument). Jenis penelitian yang digunakan adalah jenis deskriptif kualitatif yang mempelajari masalah-masalah yang ada serta tata cara kerja yang berlaku (Sugiyono 2012 : 11). Data yang digunakan berupa data primer dan sekunder. Data primer diperoleh dari wawancara mendalam dengan beberapa narasumber sedangkan data sekunder diperoleh dari berbagai dokumen pemerintah daerah Kota Jambi yang dapat mendukung penelitian ini. Dalam menganalisis data dilakukan secara deskriptif kualitatif yakni data yang terkumpul akan dikategorisasi, kemudian dianalisis secara deskriptif hingga diperoleh kesimpulan berupa permasalahan Kota dan tantangan apa saja yang dihadapi oleh Kota Jambi dalam mewujudkan Smart City secara berkelanjutan.

\section{PEMBAHASAN}

\section{Wajah Kota Jambi Menuju Smart City}

Dalam rangka mewujudkan Smart City, pemerintah Kota Jambi telah mengimplementasikan inovasi kebijakannya melalui salah satu program andalan yang disebut kampung bantar merupakan sebuah program kawasan pemukiman ditingkat kelurahan atau RT yang bertujuan untuk meningkatkan pertumbuhan pembangunan bidang ekonomi, sosial, dengan mengedepankan dan melestarikan budaya, adat istiadat dan agama. Bantar sendiri adalah kepanjangan dari bersih, aman dan pintar. Program yang menjadi andalah bagi pemerintah Kota ini diperlombakan setiap tahunnnya untuk memotivasi masyarakat agar menjadikan kawasannya sebagai kampung yang bersih, aman dan pintar. Ketiga indikator tersebut dijelaskan sebagai berikut :

1. Bersih:

a. Memiliki sarana dan prasarana permukiman dan perumahan sehat dan tertata rapi. 
b. Memiliki sarana dan prasarana lingkungan yang memadai.

c. Memiliki tingkat partisipasi dan kesadaran masyarakat dalam menjaga kebersihan lingkungan.

d. Memiliki ruang terbuka hijau, bebas dari polusi

e. Memiliki tingkat kesadaran dalam Pemanfaatan lahan tidur untuk kebutuhan rumah tangga dan masyarakat.

f. Memiliki sanitasi lingkungan yang sehat dan baik.

g. Memiliki jiwa dan semangat gotong-royong, serta nilai-nilai kesetiakawanan sosial dalam kehidupan bermasyarakat, berbangsa dan bernegara.

\section{Aman:}

a. Lingkungan yang bebas dari bahaya NAPZA dan MIRAS

b. Lingkungan yang bebas dari tindakan kriminalitas

c. Lingkungan yang bebas dari tindakan prostitusi dan Asusila

d. Lingkungan yang bebas dari tindakan kasus KDRT, perceraian rumah tangga, diskriminasi dan eksploitasi anak.

e. Lingkungan yang masyarakat senantiasa menjaga semangat musyawarah untuk

f. mufakat dalam menyelesaikan kegiatan dimasyarakat khususnya dibidang

g. pemerintahan, pembangunan, kemasyarakatan, keamanan dan ketertiban.

h. Memiliki tingkat kesadaran berpolitik dan hukum yang tinggi.

i. Lingkungan yang senantiasa menjaga dan menjunjung tinggi nilai-nilai adat istiadat,

j. budaya bangsa dan norma-norma hukum ditengah-tengah masyarakat.

\section{Pintar:}

a. Memiliki lembaga pemberdayaan ekonomi masyarakat.

b. Memiliki lembaga dan kelompok pendidikan dalam peningkatan sumber daya manusia

c. Memiliki kelompok organisasi sosial, kemasyarakatan, kepemudaan dan keagamaan.

d. Lingkungan yang bebas dari buta aksara dan angka putus sekolah

e. Lingkungan yang bebas dari tingkat pengangguran

f. Lingkungan yang bebas dari tingkat kematian ibu hamil dan balita.

g. Lingkungan yang mampu menggali dan mengelola potensi sumber daya manusia

h. Dalam meningkatkan kesejahteraan sosial dan ekonomi masyarakat. 
Tujuan Program Kampung Bantar adalah untuk menjadikan suatu lingkungan perkampungan terkecil lingkup RT di masyarakat yang berwawasan lingkungan bersih dan sehat, tercukupinya fasilitas sanitasi sarana dan prasarana lingkungan memadai, permukiman layak huni dan tertata rapi (nyaman), aman dan tertib, tingkat kehidupan sosial ekonomi masyarakat yang cukup baik (produktif), serta senantiasa menjaga semangat jiwa gotong royong, nilai-nilai agama, kesetiakawanan nasional, adat istiadat dan norma-norma hukum dalam kehidupan bermayarakat, berbangasa yang lebih berakhlak, beradat dan berbudaya. (kampung bantar jambiKota.go.id).

Jika dibandingan dengan konsep yang Smart City menurut Cohen yang terdiri dari 6 indikator, kampung bantar hanya mencakup 3 dari 6 dimensi smart city yang dikemukakan oleh Cohen. Namun jika dianalisa lebih dalam kampung bantar bisa menjadi pondasi awal bagi Pemerintah Kota Jambi untuk mewujudkan Kota pintar. 3 indikator kampung bantar yakni : Pertama, Indikator bersih, lingkungan yang bersih dengan mengandalkan asas gotong royong, lingkungan yang asri ditumbuhi tanaman-tanaman obat keluarga. Dalam pengelolaan sampah, setiap RT memiliki bank sampah masing-masing yang disebut bank sampah mini dengan 1 bank sampah induk. Menariknya di Kelurahan Eka Jaya, Paal Merah, Kota Jambi bank sampah dikelurahan tersebut memberikan kepercayaan kepada ibu-ibu dalam mengorgadinisir pengelolaan sampah secara terstruktur, masyarakat belajar mengelola sampah secara mandiri dengan cara memisahkan sampah yang bernilai guna untuk diserahkan pada bank sampah sehingga hasil dari pengumpulan sampah tersebut bisa juga sangat ekonomis. Jadi, selain lingkungan menjadi bersih, semangat budaya gotong royong mulai tumbuh kembali ditengah masyarakat Kota disebut oleh Meno dan Mustamin lebih dikenal memiliki karakter individual, egoisme, materialistik dan penuh kemewahan dengan gedung-gedung yang menjulang tinggi yang menjanjikan sebagai tempat kesuksesan bermula (Adon Nasrullah, 2017 : 62). Indikator bersih kampung bantar disebut oleh Cohen sebagai Smart Environment.

Kedua, Indikator Aman. indikator ini dijadikan untuk menciptakan lingkungan yang aman terhadap segala macam gangguan, seperti kriminalitas, narkoba bebas dari prostitusi, bencana alam dan lainnya. Untuk mewujudkan lingkungan yang aman, pemerintah mengaktifkan kembali pos kamling (pos keamanan keliling). Bukan kampung bantar namanya jika tidak memiliki pos kamling, Menurut Ibu Hj. Mursidah sebagai camat Paal Merah Kota Jambi, ciri khas kampung bantar adalah pos kamlingnya, tidak ada kampung bantar yang tidak memiliki pos kamling. Pos kamling dapat memberikan rasa aman yang diadakan setiap malam 
secara bergiiliran oleh masyarakat selain itu dapat dijadikan sebagai wadah bagi masyarakat Kota dalam menciptakan kerja sama saling tolong menolong dalam menyelesaikan masalah dengan sukarela, terkikisnya sifat individual dan egosentris yang kuat dilapisan masyarakat serta interaksi dan komunikasi yang awalnya renggang dapat teratasi. Alhasil, terbentuknya sistem keamanan dan hubungan sosial yang erat ditengah arus globalisasi dan modernisasi yang telah menjadikan corak kehidupan yang begitu kompleks ditengah kehidupan masyarakat Kota. lingkungan yang aman merupakan salah satu indikator Smart City Cohen yakni Smart Living.

Ketiga, Indikator pintar, dijelaskan oleh Ibu $\mathrm{Hj}$. Mursidah sebagai camat Paal Merah Kota Jambi, Indikator pintar yakni tidak ada lagi masyarakat yang buta huruf yang kedua tidak ada lagi anak-anak yang putus sekolah. Untuk menciptakan masyarakat pitar maka disetiap RT terdapat sudut baca perpustakaan RT yang dikelola oleh masyarakat bahan bacaan yang didapatkan juga merupakan hasil dari partisipasi masyarakat dengan cara mengumpulkan bahan bacaan melalui sumbangan sukarela. Dimensi pintar menurut Cohen disebut Smart People. Dimensi ini yang paling terpenting diantara semuanya, dibutuhkan partisipasi masyarakat yang kuat dan juga sumber daya manusia yang berkualitas untuk mengembangkan dan mempertahankan program kampung bantar. Akan percuma jika teknologi yang maju, infrastruktur yang baik namun tidak bisa dimanfaatkan dan dikelola dengan baik oleh masyarakat.

Bagaimana dengan 3 dimensi smart city lainnya? Seperti smart Government, Smart Mobility dan Smart Economy? Ketiga dimensi tersebut berada diluar program Kampung Bantar. Hal ini bisa dilihat dari tekad pemerintah Kota jambi untuk terus berinovasi meningkatkan pelayanan publik yang dapat mempermudah masyarakat, menurut Cohen, smart government mengacu pada prinsip Good Government bertujuan untuk mengurangi kesenjangan Kota diitngkat kelurahan hingga kecamatan tidak hanya dalam hal pembangunan fisik tetapi juga meningkatkan kualitas aparatur pemerintahan yang responsif didukung dengan teknologi informasi.

Smart Governement ditunjukkan oleh pemerintah Kota jambi melalui berbagai inovasi kebijakan diantaranya program kampung bantar untuk mewujudkan lingkungan yang aman dan nyaman, kemudian melalui program bangkit berdaya mampu menciptakan pemerintah yang responsif dan meningkatkan masyarakat yang partisipasif melalui pengajuan proposal yang diusulkan oleh masyarakat kepada pemerintah Kota, melalui usulan tersebut pemerintah dapat mengetahui permaslaahan yang dihadapi serta kebutuhan apa saja yang diinginkan oleh 
masyarakat, selanjutnya pemerintah Kota juga menerapkan E-Planning yakni mengkombinasikan antara birokrasi dengan media sosial. Setiap perencanaan pembangunan akan diupload dimedia sosial, kemudian peran aktif dan turut sertanya masyarakat dapat dilihat dari komentar ataupun likers dalam setiap postingan perencanaan pembangunan. Perencanaan pembangunan tersebut akan memancing respon masyarakat tentunya menuai pro dan kontra. Perencanaan pembangunan dapat ditindaklanjuti jika mendapat respon positif dari masyarakat melalui sosial media dilihat dari jumlah likes atau penyuka postingan yang dipublikasi oleh pemerintah. Selanjutnya, konsep traffic light yang diatur dengan Closed Circuit Televition (CCTV) dan Integrated Traffic System Management, dengan sistem ini antrean panjang dilampu lalu lintas dapat datasi karena dapat diatur secara otomatis. Dalam meningkatkan dan mempermudah pelayanan publik pemerintah meluncurkan aplikasi SIKOJA sistem informasi Kota Jambi. Masyarakat bisa dengan mudah mengakses melalui android untuk mendapatkan informasi seputar Kota Jambi seperti tempat wisata, informasi daerah, berita terkini dalam 1 aplikasi.

Smart Mobility yang berkaitan dengan infrastruktur dan transportasi yang efisien, terpadu dan ramah lingkungan. Faktanya untuk mewujudkan Smart Mobility diKota Jambi seperti bus kapsul yang menjadi alternatif transportasi publik karena angkutan umum yang beroperasi dianggap tidak mampu menangani permasalahan Kota yang ditambah dengan lajunya arus urbanisasi di Kota Jambi. Dari ratusan unit angkot hanya setengah yang beroperasi. Green transportasi yang harusnya menjadi prioritas utama untuk mendukung pengembangan Smart City di Kota Jambi nyatanya masih dalam tahap perencanaan dan belum bisa diwujudkan dalam waktu dekat.

Smart Economy diwujudkan Kota Jambi melalui pemberdayaan masyarakat melalui UMKM untuk medorong inovasi dan menumbuhkan jiwa Entrepreneurship masyarakat. berdasarkan keterangan dari Camat Paal Merah Kota Jambi UMKM yang sangat maju, seperti RT 33 talang bakung mereka punya produk industri rumahan, kolam ikan dan lainnya yang dijual dan dikonsumsi sendiri dilingkungan.

\section{Permasalahan Perkotaan dan Tantangannya}

Pemerintah Kota Jambi dengan tekad yang begitu kuat telah berhasil dalam mewujudkan smart city meski dengan berbagai tantangan dan kekurangan yang masih perlu dievaluasi kedepannya. Chourabi dkk mengelompokkan beberapa faktor dalam mensukseskan Smart City diantaranya : 


\begin{tabular}{|c|c|c|}
\hline Faktor & Masalah & Tantangan \\
\hline $\begin{array}{l}\text { Management } \\
\text { and } \\
\text { Organization }\end{array}$ & $\begin{array}{l}\text { Seluruh elemen } \\
\text { pemerintahan } \\
\text { Kota Jambi }\end{array}$ & $\begin{array}{l}\text { - Dalam mewujudkan smart city, harus adanya komunikasi } \\
\text { yang baik antar lembaga pemerintahan dari Kota } \\
\text { kecamatan kelurahan hingga RT } \\
\text { - Dibutuhkan kesadaran yang tinggi dan tekad yang kuat } \\
\text { - Perbedaan pendapat dalam mencapai tujuan } \\
\text { - Konflik }\end{array}$ \\
\hline Technology & $I C T$ & $\begin{array}{l}\text { - Kurangnya pemanfaatan ICT baik dibidang infrastruktur, } \\
\text { pemerintahan dan lainnya meski fasilitas telah memadai } \\
\text { seperti e-governmentkonsep traffic light yang diatur dengan } \\
\text { Closed Circuit Televition (CCTV) dan Integrated Traffic } \\
\text { System Management yang telah dijanlankan oleh } \\
\text { pemerintah Kota Jambi akan tetapi masih adanya } \\
\text { kekurangan dan evaluasi kembali dikarenakan kurangnya } \\
\text { SDM bidang IT. }\end{array}$ \\
\hline Governance & E-Government & $\begin{array}{l}\text { - Pemerintah Kota Jambi memiliki hambatan kurangnya } \\
\text { APBD maka dibutuhkan model pembiayaan yang mampu } \\
\text { menjawab tantangan kedepan } \\
\text { - Kurangnya aparatur pemerintahan yang memiliki } \\
\text { keterampilan dibidang penguasaan teknologi dan informasi } \\
\text { - Memanfaatkan sumber daya yang dimiliki untuk } \\
\text { kesejahteraan masyarakat bukan untuk kepentingan pribadi } \\
\text { - Belum adanya inovasi children friendly city, lingkungan } \\
\text { yang aman dan nyaman tidak hanya dirasakan oleh warga } \\
\text { tetapi juga anak-anak }\end{array}$ \\
\hline Policy & $\begin{array}{l}\text { - Kampung } \\
\text { Bantar } \\
\text { - Bangkit } \\
\text { Berdaya } \\
\text { - E-Plannig } \\
\text { - traffic light } \\
\text { dan CCTV } \\
\text { - Aplikasi } \\
\text { SIKOJA }\end{array}$ & $\begin{array}{l}\text { - Berbagai inovasi yang telah di kembangkan oleh } \\
\text { pemerintah Kota demi mewujudkan smart city masih } \\
\text { memiliki kendala yang sama yakni SDM (Sumber Daya } \\
\text { Manusia) } \\
\text { E-planning traffic light dan CCTV yang berhubungan } \\
\text { dengan teknologi dalam pengimplementasiannya seringkali } \\
\text { tidak berjalan baik karena kekurangan tenaga ahli bidang } \\
\text { IT } \\
\text { Kampung bantar merupakan program andalan pemerintah, } \\
\text { namuan program ini seringkali dianggap masyarakat } \\
\text { sebagai ajang perlombaan yang akan berakhir sejalan } \\
\text { dengan berakhirnya perlombaan, maka diperlukan motivasi } \\
\text { dan tekad yang kuat oleh pemerintah dari tingkat RT, } \\
\text { kelurahan hingga kecamatan untuk membagkitkan kembali } \\
\text { semangat masyarakat dalam mewujudkan kampung bantar } \\
\text { yang berkelanjutan. }\end{array}$ \\
\hline $\begin{array}{l}\text { People and } \\
\text { Communities }\end{array}$ & $\begin{array}{l}\text { Masyarakat } \\
\text { Kota, } \\
\text { Bank Sampah, } \\
\text { dan anggota } \\
\text { FK2L }\end{array}$ & $\begin{array}{l}\text { - Dari } 11 \text { kecamatan dan } 62 \text { kelurahan hanya kelurahan Eka } \\
\text { Jaya Kecamatan Paal merah Kota Jambi yang memiliki } \\
\text { kamung bantar paling banyak sedangkan kelurahan lainnya, } \\
\text { beberapa bakan belum sama sekali menjadikan } \\
\text { lingkungannya sebagai kampung bantar. Hal ini dapat } \\
\text { menyebabkan kesenjangan antar wilayah Kota Jambi jika } \\
\text { seluruh stakeholder tidak saling bekerja sama untuk } \\
\text { menjadikan lingkungannya sebagai kempung bantar. } \\
\text { Peningkatan partisipasi masyarakat }\end{array}$ \\
\hline
\end{tabular}




\begin{tabular}{|c|c|c|}
\hline & & $\begin{array}{l}\text { - } \begin{array}{l}\text { Belum adanya keterbukaan informasi akibat kurangnya } \\
\text { sosialisasi }\end{array} \\
\text { - } \begin{array}{l}\text { Dibutuhkan komitmen, kerjasama RT selaku lembaga } \\
\text { pemerintahan lingkup terkecil yang dapat mendorong } \\
\text { masyakarat untuk berpartisipasi aktif }\end{array}\end{array}$ \\
\hline Economy & UMKM & $\begin{array}{l}\text { - Perlunya pemberdayaan dan pengembangan UMKM secara } \\
\text { berkesinambungan } \\
\text { - Revolusi industri } 4.0 \text { menjadi tantangan baru bagi Kota } \\
\text { Jambi }\end{array}$ \\
\hline $\begin{array}{l}\text { Built } \\
\text { Infrastructure }\end{array}$ & $\begin{array}{l}\text { Bus Kapsul } \\
\text { Green } \\
\text { Transportasi }\end{array}$ & $\begin{array}{l}\text { - Adanya bus kapsul dapat menambah polusi udara } \\
\text { - Berdasarkan pola pikir dan kebiasaan masyakarat Kota } \\
\text { Jambi yang lebih memilih menggunakan kendaraa pribadi } \\
\text { maka keberadaan bus kapsul hanya berupa pajangan tidak } \\
\text { dapat dimanfaatkan oleh masyarakat } \\
\text { - Rancangan green transportasi harus dapat direalisasikan } \\
\text { oleh pemerintah Kota Jambi bukan hanya sekedar wacana } \\
\text { karena sangat menunjang dalam mewujudkan smart city. }\end{array}$ \\
\hline $\begin{array}{l}\text { The natural } \\
\text { environment }\end{array}$ & $\begin{array}{l}\text { Pengelolaan } \\
\text { sampah } \\
\text { Pemanfaatan } \\
\text { ruang hijau } \\
\text { terbuka }\end{array}$ & 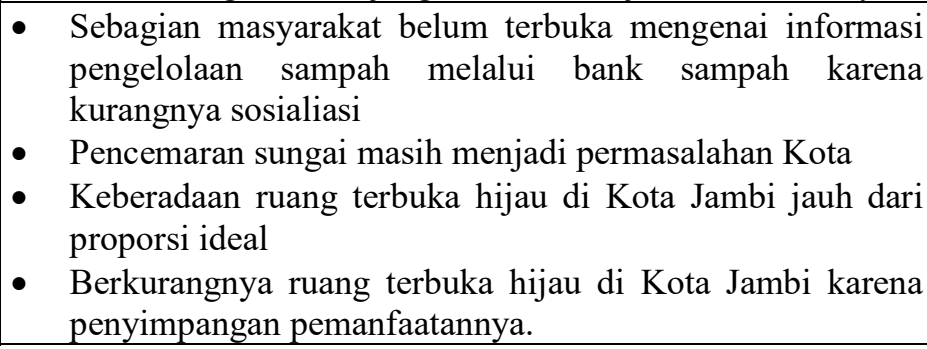 \\
\hline
\end{tabular}

Berdasarkan Peraturan Daerah Kota Jambi Nomor 9 Tahun 2013 tentang Rencana Tata Ruang Wilayah Kota Jambi Tahun 2013-2033. Kota Jambi dengan luas mencapai 17,553 hektar membutuhkan ruang terbuka hijau publik minimal 3.510,60 hektar dan ruang terbuka hijau privat minimal 1.755,30 hektar maka dari itu Kota Jambi masih kekurangan ruang terbuka hijau publik sebanyak 2.220,13 hektar dan ruang terbuka hijau privat sebanyak 774,36 hektar. Hal ini membuktikan, Kota Jambi masih belum memenuhi 30\% ruang terbuka hijau sebagaimana yang tercantum dalam Undang-Undang Republik Indonesia Nomor 26 Tahun 2007 tentang Penataan Ruang (Lestari, 2014). Semua kecamatan di Kota Jambi saat ini terutama Kecamatan Jambi Timur belum ada sama sekali RTH taman Kota dan hutan Kota, sedangkan kecamatan danau teluk dan kecamatan pelayangan baru sebagian kecil dan RTH yang suda ada disetiap kecamatan adalah RTH pemakaman (Ulil Amri, 2018 : 42)

Ruang terbuka hijau seringkali disalahgunakan pemanfaatannya, adanya peralihan fungsi lahan yang digunakan untuk membangun Hotel, Mall, pembangunan Ruko dan masih banyak lainnya. Tidak heran jika banjir, jumlah emisi karbon yang semakin menipis ditambah dengan polusi udara yang meningkat sejalan dengan arus urbanisasi di Kota Jambi menjadi 
permasalahan lingkungan yang patut menjadi perhatian pemerintah Kota. Sehingga dibutuhkan kebijakan pengembangan Kota hijau, karena pada dasarnya Smart City bertujuan mengembangkan sumberdaya dan menciptakan lingkungan dan kualitas hidup yang aman dan nyaman.

Jika kita mengartikan bahwa Smart City tidak melulu berbicara mengenai teknologi, benar adanya, tetapi jika penyataannya berubah menjadi "Smart City tidak harus berbicara mengenai teknologi" maka hal ini sangat salah. Pemerintah adalah penggerak dan aktor utama dalam memanfaatkan kemajuan teknologi baik dari segi tata kelola pemerintahan yang dapat mempermudah dalam megelola sumber daya yang sudah ada secara efesien dan efektif, meningkatkan kualitas pelayanan publik, infrastruktur dan pembangunan, serta membentuk sumber daya manusia yang berkualitas. Kemajuan teknologi tidak dapat dihentikan, semakin hari semakin menunjukkan kemajuannya. Dengan semakin bayaknya Kota di Indonesia menerapkan Smart City, negara maju telah mempersiapkan diri dalam menyambut era revolusi industri 4.0 meningkatkan ekonomi dalam rangka mempercepat pertumbuhan dan pembangunan negara dengan memajukan ekonomi selaras dengan pengembangan Smart City.

Menurut Kagerman dkk dalam Hoedi dan Wahyudi istilah revolusi industri 4.0 lahir di Jerman pada tahun 2011 ketika diadakan Hannover Fair (Hoedi dan Wahyudi, 2018 : 18). Jerman menjadi penggerak utama dalam menyusun roadmap mengenai ekonomi berbasis digital. Tak ingin ketinggalan Indonesia melalui kementerian perindustrian tengah melaksanakan langkah-langkah strategis dalam mempercepat terwujudnya visi nasional yang ditetapkan untuk memanfaatkan peluang tersebut. salah satu visinya yakni menjadikan Indonesia masuk dalam 10 besar negara yang memiliki perekonomian terkuat di dunia pada tahun 2030 (Venti, 2018 : 19). Lalu apa hubungannya revolusi industri 4.0 dengan Smart City? Pada dasarnya konsep Industri 4.0 yang memanfaatkan sensor, Smart System, Big Data, yang beberapa hal tersebut dipakai juga dalam penerapan konsep smart city (Achmad Djunaedi, 2018). Dengan adanya konsep ini, dapat memperkuat dimensi smart city tertuma pada dimensi Smart Economy melalui perkembangan industri berdasarkan aspek Internet of Things (IoT) yang biasanya dipakai dalam pengembangan smart systems/smart products/sensor, juga berkaitan Smart Mobility karena salah satu konsep industri 4.0 diantaranya yakni Internet of Services (IoS) yang mencakup intelligent transport dan logistics (Smart Mobility, Smart Logistics), serta berkaitan dengan Smart Environment, yakni pada aspek Internet of Energy (IoE) yng dipakai untuk mengatur agar sumber daya energi dimanfaatkan dengan tepat 
(Achmad Djunaedi, 2018). Dengan isu tersebut tentunya semakin menambah tantangan Kota Jambi dalam mewujudkan Smart City.

\section{Smart City Sebagai Potensi dalam Menyelesaikan Masalah Kota Jambi}

Dibalik permasalahan yang dihadapi sebagai tantangan Kota Jambi dalam mewujudkan Smart City, langkah awal Kota Jambi dengan program Kampung Bantar mampu membawa perubahan yang sangat besar dalam kemajuan Kota Jambi. Smart City hadir sebagai potensi dalam menyelesaikan masalah perkotaan diantaranya :

1. Meningkatkan partisipasi masyarakat dalam membangun Kota Jambi.

2. Membangun rasa kepercayaan dan hubungan yang baik antara masyarakat dan pemerintah Kota Jambi.

3. Mengurangi angka kemiskinan, secara tidak langsung dapat meningkatkan kesejahteraan masyarakat Kota Jambi dengan terbukanya lapangan kerja melalui UMKM.

4. Mempermudah pemerintah merancang kebijakan yang tepat sesuai dengan kebutuhan masyarakat melalui proposal kebijakan yang dirancang oleh masyarakat dalam program kampung bantar.

5. Menjadikan Kota Jambi sebagai Kota yang layak huni dengan lingkungan yang aman dan nyaman.

\section{KESIMPULAN}

Hasil dari pemaparan penelitian ini dapat ditarik kesimpulan kampung bantar sebagai modal utama pemerintah Kota Jambi dalam mewujudkan Smart City terdiri dari Tiga dimensi, Smart Living, Smart Environment, dan Smart People. Namun, tentunya dalam mengimplementasikannya terdapat beberapa kekurangan, diantaranya sosialisasi yang kurang mengenai pengelolaan sampah, beberapa kelurahan hanya memanfaatkan kampung bantar sebagai program momentum sehingga tidak adanya keberlanjutan.

Tiga dimensi Smart City lainnya dapat ditemukan diluar program kampung bantar, seperti Smart Government melalui E-Government, Smart Economy melalui UMKM masih dirasa kurang dalam menciptakan Smart Economy sedangkan Smart Mobility, dilihat dari transportasi umum "bus kapsul" akan yang segera diluncurkan sedangkan Green Transportation masih dalam tahap perencanaan. Peluncuran bus kapsul sebagai transportasi umum yang dapat mempermudah masyarakat justru menjadi masalah baru dan tantangan bagi 
pemerintah Kota Jambi, Pertama,. Polusi udara semakin meningkat, Kedua, Pemerintah harus mengubah pola hidup masyarakat Kota Jambi yang terbiasa menggunakan kendaraan pribadi dibandingka transportasi umum. Maka untuk menciptakan Smart Mobility, Green Trasportation harus menjadi program yang tidak hanya sebatas perencanaan saja tetapi semoga dapat direalisasikan. Permasalahan lainnya ditambah dengan ruang terbuka hijau di Kota Jambi yang semakin menipis. Semua ini harus menjadi perhatian pemerintah Kota Jambi.

Tantangan utama adalah sumber daya manusia baik dari aparatur pemerintah maupun masyarakat. Kota Jambi tidak boleh merasa puas dengan penghargaan yang telah diperoleh dengan membawa kampung bantar sebagai program unggulan yang terbukti sukses dalam membawa Kota Jambi diakui secara internasional sebagai Kota pintar. Di balik kesuksesan tersebut faktanya pemerintah perlu sadar untuk terus bekerja keras dalam membangun sumber daya manusia yang berkualitas terutama dalam menghadapi revolusi industri 4.0, era dimana seluruh dunia bersaing meningkatkan pertumbuhan ekonomi dan industri yang efesien dan efektif dengan memanfaatkan teknologi. Indonesia, termasuk Kota Jambi akan semakin jauh dari ketertinggalan jika hanya duduk diam berpangku tangan sebagai penonton. Untuk mempersiapkan sumber daya manusia, pemerintah Kota Jambi tidak bisa sendiri butuh adanya kerjasama perguruan tinggi serta stakeholder lainnya.

\section{DAFTAR PUSTAKA}

Amri, Ulil. (2018). Kebutuhan Ruang Terbuka Hijau di Kota Jambi. Jurnal Pembangunan Berkelanjutan Universitas Jambi: Volume 1 Nomor 1

Annisah, Usulan. (2017). Perencanaan Smart City : Smart Governance Pemerintah Daerah Kabupaten Mukomuko. Jurnal Masyarakat Telematika dan Informasi: Volume 8 Nomor 1.

Chourabi, dan Hafedh, Taewoo Nam dkk. (2019). Understanding smart cities : an integrative framework. Diunduh dari https://www.researchgate.net/publication/254051893 pada 11 Februari 2019

Djunaedi, Achmad. (2018). Tantangan Penelitian Industrialisasi 4.0 : Ari dan Nilai Riset pada Karir Dosen serta Kemajuan Sains \& Teknologi Komisi Ilmu Sosial- Akademi Ilmu Pengetahuan Indonesia. Yogyakarta: Pascasarjana UGM 
Eka Venti, Satya. (2018). Strategi Indonesia Menghadapi Industri 4.0, Bidang Ekonomi dan Kebijakan Publik, Pusat Penelitian Badan Keahlian DPR RI. Volume X, Nomor 09/I/Puslit/Mei/2018.

Lestari Fitriani, Sitanggang. (2014). Kebijakan Pengembangan Taman sebagai Pelestarian Ruang Terbuka Hijau (RTH) di Kota Jambi oleh Dinas Lingkungan Hidup Kota Jambi. Jambi: Jurnal Ilmu Pemerintahan Universitas Jambi

Mohanty, Saraju P. dan Uma Choppali dkk. (2019). Everything you wanted to know about smart cities. Diunduh dari https://www.researchgate.net/publication/306046857 pada 11 Februari 2019

Nasrullah Adon, Jamaludin. (2017). Sosiologi Perkotaan Memahami Masyarakat Kota dan Problematikanya. Bandung : CV Pustaka Setia

Nugraha, M. Quadrat. (2014). Manajemen Strategis Pemerintahan. Jakarta : Universitas Terbuka

Prasetyo, Hoedi dan Wahyudi Sutopo. (2018). Industrial 4.0 : Telaahklasifikasi Aspek dan Arah Perkembangan Riset. Jurnal Teknik Industri Universitas Diponegoro: Volume 13 Nomor 1

Sugiyono. (2012). Memahami Penulisan Kualitatif. Bandung : Alfabeta 